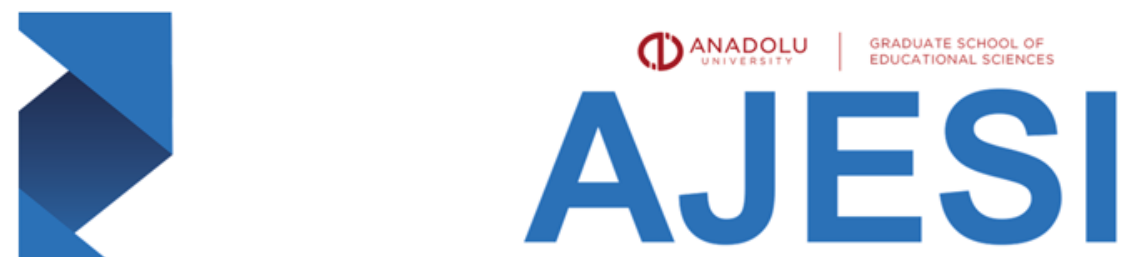

ANADOLU JOURNAL OF EDUCATIONAL SCIENCES INTERNATIONAL

DOI: 10.18039/ajesi.881471

\title{
Undergraduate Architecture Students' Perceptions of the Reasons for Their Choice(s) of Profession ${ }^{1}$
}

\author{
Derya YORGANCIOĞLU², Sevinç TUNALI ${ }^{3}$, Meltem ÇETINEL ${ }^{4}$
}

Date Submitted: 17.02.2021 Date Accepted: 14.06.2021

Type $^{5}$ : Research Article

\begin{abstract}
This study aims to analyze the factors, driven by intrinsic and/or extrinsic motivations, that affect the students' choice(s) of profession before entering the school of architecture and to reveal how the participants' perceptions of their "self-efficacy" about becoming an architect altered in parallel to the skills they acquire during their professional education. The research, based on the qualitative research methodology, is undertaken in a Bachelor of Architecture degree program in a private university in Istanbul and the data was collected through the participation of 40 undergraduate architecture students from different class levels. The data collection procedures covered four recorded focus group interviews with students at different class levels and the interview transcriptions were analyzed through qualitative content analysis. The results regarding the reasons for studying architecture has revealed that the participants are influenced by (1) their self-perceptions, which overlap with the profession-related qualities and (2) the influence of their social environment and families. It is shown that the professional education that the participants have received has improved their design skills and supported their selfefficacy beliefs in this regard, but made them feel insufficient about technical-practical skills. The research findings have implications for the students who think to study architecture, the secondary education teachers, and the administrators and instructors of schools of architecture for various reasons: by uncovering the interrelated dynamics and requirements of the architectural profession and education, these findings may guide the attempts to choose a profession compatible with individuals' capabilities and orientations and to structure a balanced architectural curriculum.
\end{abstract}

Keywords: architectural education, architectural profession, design skill, profession choice, self-efficacy perception

Cite: Yorgancıoğlu, D., Tunalı, S. \& Çetinel, M. (2021). Undergraduate architecture students' perceptions of the reasons for their choice(s) of profession. Anadolu Journal of Educational Sciences International, 11(2), 752-770. https://doi.org/10.18039/ajesi.881471

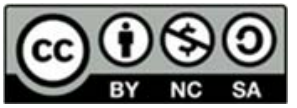

\footnotetext{
${ }^{1}$ This work was supported by the Scientific and Technological Research Council of Turkey (TÜBiTAK) under Grant 215K234. Special thanks to the faculty and students in the Department of Architecture at Altınbaş University for their participation in the research.

2 (Corresponding author) Assist Prof. Dr., Özyeğin University, Faculty of Architecture and Design, Department of Architecture, Turkey, derya.yorgancioglu@ozyegin.edu.tr, https://orcid.org/ 0000-0002-5583-3515

${ }^{3}$ Dr., Education, Industry and Technology Institute (ESTEN), Turkey, sevinctunali@tasam.org, https://orcid.org/ 0000-0001-9736-5716

4 Instructor, İstanbul Kültür University, Faculty of Architecture, Department of Interior Architecture and Environmental Design, Turkey, m.cetinel@iku.edu.tr, https://orcid.org/ 0000-0002-9010-3227

5 This research study was conducted with Research Ethics Committee approval of Altınbaş University, Faculty of Engineering and Architecture, dated 03.09.2015 and issue number 2015/5; 65760937.604.01.01/68-506.
} 


\section{Introduction}

The choice(s) of profession is a factor that directly affects individuals' productivity, satisfaction and self-efficacy perceptions both during and after their education. Although it has such vital importance, it can hardly be said that individuals always make their choice(s) of profession consciously or easily due to manifold reasons (Gati et al., 1996; Albion, 2000). Before tertiary education, university candidates may have both self-perceptions and profession-related perceptions. Their perceptions of themselves may be due to what they are most interested in, and their beliefs about what they are capable of. Their perceptions of the profession may be informed by their effort to harmonize the profession with their orientations and skills and/or by external factors such as the family, social environment or role models. After starting to study a professional field, by getting familiar with the field-specific ways of thinking and doing and developing skills, the students' self-perceptions and their perceptions about the field of profession may alter. The cultivation of field-specific skills can support their self-perceptions and increase their belief that they are appropriate for this profession; or, in some cases, this may also result in feelings of inadequacy and decreased self-efficacy beliefs in some areas of the profession. High school students consider studying architecture for a variety of reasons: the status of architecture as a prestigious profession, the general social respect accorded to architects, family members already involved in architecture, being creative or skilled at drawing, the drive to create something permanent in the world, and so on. The choice is sometimes made independently, but most of the time, family, friends, and other social factors are key influencers of a student's decision to pursue architecture. The pedagogical approaches that the students encounter when they start studying in an architecture department, and the modes of thinking and professional practices that these approaches engender, transform students' previous perceptions regarding the profession and the social profile of the architect (İlerisoy \& Aycı, 2019).

The connection between "vocational interest" and "educational pathway" of students has been the topic of various researches in the literature on career choice and vocational psychology (Care, 1996; Elsworth et al., 1999; Patrick et al., 2011). The discussions dwell on the role of personality of the individual as the basis of personal interest, and how this interest evolves into a vocational choice through career decision-making process (Wang et al., 2006; Martincin \& Stead, 2015; Oakland et al., 2001). Besides personal interest, it is also pointed those different variables such as the "values, motivation, planning, time perspectives, curiosity, exploration, stereotyping, and the availability of suitable role models" may inform the career choice of individuals (Oakland et al., 2001, p. 298). According to the "vocational choice theory" by Holland $(1959,1997)$, the link between personal interest and the self-understanding of individuals that determine the subjects they prefer to study or perform is underscored. For Holland, individuals should better prefer subjects or vocations that are congruent with their personalities (cited in Tang 2009; Nauta 2010; Xu 2019; Sheldon et al., 2019). Holland defines the vocational interests of an individual as a "constellation of interests, skills, and dispositions" and he categories them under six groups as "Realistic", "Investigative", "Artistic", "Social", "Enterprising" and "Conventional" (Sheldon et al., 2019, p. 29). An individual may have interest in applied subjects or learning by doing, which may be indicative of "realistic interests"; problem-solving abilities may indicate to "investigative interest" of an individual (Patrick et al., 2011 , p. 62). In a similar vein, the interest in subjects such as art, creativity and design shows individual's orientation towards artistic vocations. As underlined by Sheldon et al. (2019, p. 29) individuals' interests may overlap with more than one category, demonstrating a "meaningful convergence between the six types and other personality systems." According to Holland's 
career choice theory, when the conditions of the working/educational environment and the vocational choice determined by the personal interest are matched with each other, the individual is more likely to be successful (Tang, 2009).

Holland's remark on the role of personal interest in career choice is also addressed in the discussions on the concept of "self-concordance," according to which one's goals are representative of either "explicit conscious beliefs and processes" of individuals or their "deeper or more implicit personality preferences and potentials" (Sheldon et al., pp. 29-31). In both cases, as much as the perception and belief of the individual's self-concordance increases, they begin to internalize their goals. Another essential concept addressed in the discussions on career choice-making process is 'self-efficacy,' according to which as an individual gains experience in a certain subject or field, the belief in his/her self-efficacy increases, supporting the inclination towards a field of study (Betz \& Borgen, 2000; Patrick et al., 2011). In the view of Bandura (1986), an increase in persons' belief in their ability to perform a task successfully encourages the individuals to perform any given task better; thus, selfefficacy is also related to "the individual's expectations about future performance in specific contexts" (Patrick et al., 2011, p. 62). Therefore, it is pointed out that personal interest and selfefficacy work together informing the vocational or academic choice of an individual (Lent et al., 1986; Brown et al., 2000).

In the literature on career choice and professional psychology, the values or motivations based on "internal" or "external" variables are emphasized (Super, 1970, 1973; Dagenais, 1998; Sheldon et al., 2019). Dagenais (1998) points to "creativity, intellectual stimulation, altruism, esthetics, and management" as the intrinsic values that play a part in the formation of a vocational choice (cited in Fouad et al., 2015, p. 204). According to the "expectancy-value theory", the "interest" or "enjoyment" that a person associates with a subject or a vocation are defined as an aspect of intrinsic motivation (Jung and McCormick, 2011, pp. 76-77). Holland's theory of vocational choice is considered as a "measure of intrinsic motivation," according to which an intrinsically motivated behavior is enacted because the individual has an interest in something, likes to do it or believes that having any difficulty in doing it will lead to improvement (Deci \& Ryan, 1985; Ryan \& Deci, 2017, cited in Sheldon et al., 2019, p. 39). Regarding Super's work (1970, 1973), Fouad et al., (2015, p. 199) point to the role of personal values on career decision-making that relate to the "specific interest in the activities of the work itself" or "the motivation or satisfaction from" and can also be associated with the "intangible rewards such as the benefits that an individual or society provides."

In contrast to intrinsic variables that are mostly related to intangible features, there are also extrinsic variables affecting the vocational or academic preferences of individuals that are mostly related to tangible ones. "[l]nstrumental benefits or compensation, physical settings, job titles, or other external features" (Fouad et al., 2015, p.199) and "money, appearance, or status goals" (Sheldon et al., 2019, p. 30) are examples of extrinsic variables as such. These variables can also be related to an individual's interest in prestige or lifestyle (Dagenais, 1998). Sheldon et al. (2019) underscore how "identified motivation," as an extrinsic variable, may influence people's career choice: "Identified motivation means doing $X$ because it is important, even if it is not fun" (Sheldon et al., 2019, p. 31). The value attributed to a vocational or academic task demonstrates a belief in the importance of that task and the desire to receive respect or status by performing that task (Jung \& McCormick, 2011, pp. 76-77). Among the extrinsic variables affecting the individuals choice(s) of profession is the issue of family influence. As underlined by Jung and McCormick (2011), the "perceived influence of the family 
in the choice of future occupation" is indicative of an extrinsic variable that has an impact on people's occupational decisions (Jung \& McCormick, 2011, p. 77). The influence of perceptions of family members, their previous experiences or expectations for the future on career decision-making processes are given attention in the works of Bratcher (1982), Schulenberg et al. (1984), Ulrich and Dunne (1986), Fouad et al. (2015), Whiston and Keller (2004) and Nadya et al. (2015).

Whether individuals tend to choose a profession stimulated by an internal or external variable, one's interest in a profession may be compatible with their expectations, and in some cases, a discrepancy may also be at issue. On the other hand, the harmony or consistency between one's interest in and expectations from a profession can also enable developing a "commitment" regarding their choice(s) of profession (Wang et al., 2006, pp. 312-313). When this is the case, undergraduate education experience may enhance the sense of belonging feelings about the profession that individuals have chosen.

\section{Problem Situation}

It has been observed that the relationship between "vocational interest" and "educational pathway" of students has not been adequately addressed in the architectural education literature. There are cases where social stereotypes about what architecture is and/or who the architect is, what he/she does are often not valid in architectural education settings; because there are different realities regarding both the profession and education of architecture. In a similar vein, having an inadequate perception of the characteristics of architecture can mislead individuals about matching architecture with their areas of interest. In this study, the personal experiences and perceptions conveyed by architecture students in in-depth interviews provide data to investigate the main variables and interests affecting their choice(s) of profession, and how these choices are developed or supported through the cultivation of professional skills in architectural education.

\section{Purpose and Significance of the Study}

The objective of this study is to examine the opinions of the undergraduate architecture students on the object of the elements that shape the students' choice(s) of profession before entering the school, and to unfold the degree that their preconceptions overlap with the understanding and skills they acquire after they enter the school of architecture. The study dwells on the following two main research questions:

1. What are the reasons, shaped through intrinsic and extrinsic motivations, for undergraduate architecture students to study architecture?

2. What professional skills do the architectural program help the undergraduate architecture students develop? And how do these developed skills transform their choice(s) of profession decisions?

This study aims to analyze the factors, driven by intrinsic and/or extrinsic motivations, that affect the students' vocational choices before entering the school of architecture. It is also aimed to reveal how the participants' perceptions of their "self-concordance" and "self-efficacy" about becoming an architect have changed about their undergraduate experiences and the skills that their professional education has provided or failed to provide them with. 


\section{Method}

\section{Research Design}

The research is based on the qualitative research methodology. Groat and Wang (2013) describe qualitative research as a research method based on the researcher's firsthand meeting with the subject, case or person under investigation in a specific context. The most important characteristics of qualitative research are as follows; (1) investigating the phenomenon, situation or person in their context, (2) investigating and discussing the views of stakeholders in a context or situation and interpreting these views through their interpretation filters; (3) revealing similarities and differences in their interpretations by examining how the context's stakeholders understand their situation (4) long-term communication with the context of the research subject (Groat \& Wang, 2013). The scope and objectives of qualitative research overlap with the research goal of examining the opinions of the undergraduate architecture students on the object of the elements that shape the students' choice(s) of profession before entering the school, and the degree that their preconceptions overlap with the understanding and skills they acquire after they enter the school of architecture. The host institution, Altınbaş University in Istanbul, Turkey, granted ethical approval for the research. Data was gathered through a questionnaire and it was presented to the students in a focus group meeting. Students were introduced the semi-structured interview schedules based on open-ended questions to elicit descriptions of the various dimensions of the participants' perceptions and opinions. The questions were grouped under two main headings: (1) what are the reasons for you to study architecture? (2) what professional skills do the architectural program you are studying help you develop? In order to encourage students to reflect and elaborate on their answers to the second question, the participants were also asked which subjects they consider themselves more competent and on which subjects they think they are less competent. Accordingly, it was aimed to reveal the differences between students' former conceptions of what it means to be an architect, and the conception of architecture and the architect envisioned through architectural education.

\section{Participants}

The present study was undertaken in the Bachelor of Architecture degree program at Altınbaş University, Faculty of Engineering and Architecture in 2016. The study was composed of data collection processes with the participation of a student sample of 40 architecture students from different class levels of first, second, third and fourth years, who voluntarily agreed to participate in the research (Appendix A). The relatively low number of participants had both positive and negative impacts. The number of the participants allowed to go deeper into the research subject in focus group meetings; yet, since the sample covered in this study was limited in size and represented only a group of participants from one Department of Architecture, any generalization about undergraduate architecture students' perceptions of the reasons for their choice(s) of profession is beyond the scope of this study.

\section{Data Collection Tools and Processes}

The data collection procedures covered four recorded focus group interviews with undergraduate architecture students. These procedures were chosen for elucidating how different actors involved in the same phenomenon approach from their perspectives (Creswell, 
2015). The interviews are designed as semi-structured and open-ended in a way to allow the participants to elaborate on their opinions about their experiences (Marshall \& Rossman, 2011). The CIPP (context-input-process-product) Program Evaluation Model (Stufflebeam, 2003) was taken as basis in the preparation of the interview forms and the questions were determined in a way to cover the context-input-process-product elements within the framework of the curriculum of the Architecture Department where the research was conducted. One of the researchers, who is an educational scientist, guided to the preparation of the questionnaire. A pilot study was conducted with a small group of newly graduated students in the Bachelor of Architecture program, which allowed to test the operability of measuring tools and the clarity of questions; some questions were revised to be more understandable for the participants. Focus group interviews, based on nineteen questions, were conducted with four first-year students, nine second-year students, nine third-year students and seven fourth-year students. The students were asked semi-structured and open-ended questions about the reasons of studying architecture, the degree their professional education in the architecture program provides them with enough equipment for architecture, and the subjects they consider themselves more competent and on which subjects they think they are less competent. Focus group interviews were audiotaped and the duration of each meeting ranged from one hour to two-and-a-half hours depending on the number of participants. The use of a digital voice recorder allowed the researchers to pay full attention to the interviewees. Each focus group meeting records were transcribed.

\section{Data Analysis}

After a thorough reading of the interview transcriptions, the data gathered from focus group interviews were analyzed through qualitative content analysis. Qualitative content analysis was selected as an appropriate methodology for reviewing the data and deriving themes out of the review for exemplifying the identified categories (Weber 1990; Schreier 2012; Neuandorf 2017). Through the use of content analysis method, the common and different orientations are revealed and the extent to which the common orientations overlap is determined. The data was analyzed by the group of researchers that consisted of architects and an educational scientist. The analysis of the transcriptions of the focus group interviews with undergraduate architecture students consisted of two stages. In the first phase, the rigorous reading of the transcripts allowed the researchers to derive numerous themes according to what the participants highlight and how they define their positions with reference to their own architectural education experiences. In the second phase of data analysis, the grouping, revising and re-grouping of the analyzed data led to sub-themes that specifically addressed the differences between architecture students' pre- and post-conceptions regarding the profession of architecture and architectural education. Moving back and forth between the transcriptions and the set of themes derived from the analysis of transcriptions, the researchers aimed to refine the data into a valid categorization. While the themes were obtained in the analysis phase, both a data-based framework driven by participant student discourses and a theory-based framework driven by the review of related literature were used. The strength of qualitative content analysis as a research method for this study derives from the way it helps unfold the meaning and intentions of a group of individuals and the consequences related to a context. 


\section{Validity and Reliability}

The participation of students in the research was voluntary. All participants were provided with information about the research, and the assurances of anonymity and confidentiality of data before attending to the interviews. The focus-group interviews-one pilot interview followed by four interviews-were conducted separately with a group of student at each grade level and two researchers were present at these interviews. This aimed at revealing any differences of opinion originating from different class levels. The interviews were conducted at studios and classes of the Bachelor of Architecture program in order to encourage the participants to feel themselves in their natural learning environments. A transparent and reliable basis was developed by ensuring the contribution of all researchers in the analysis processes. In the reporting of the research findings, the participants and their quotations that are taken from transcriptions of the recordings of focus group interviews have been anonymized.

\section{Role of the Researcher}

The authors of this study include two researchers who are members of the educational context under examination and one out-of-institution researcher. The presence of the out-ofinstitution researcher, who has succeeded in remaining detached, enabled not only to recognize significant dynamics from interactions within the participant groups but also to verify the interpretations of the institutional researchers during the analysis phase. All researchers contributed both to the data collection and data analysis processes.

\section{Limitations}

In this small-scale qualitative study, no claims based on the research findings are fully representative of all architecture students' choice(s) of profession in the direction of architecture. Results are reflective of the context-specific data gathered in a particular Bachelor of Architecture program and from the specific sample of students interviewed. It is possible that results could suggest similarities with other institutions; however, they are not generalizable across contexts.

\section{Ethical Issues}

A qualitative research should be based on ethical principles that ensure the confidentiality, privacy and security of the participants, during both the research design and the data collection processes. The article adheres to research and publication ethics. Ethical approval for the research was granted by the host institution (Altınbaş University Ethics Committee Meeting Report, issue number 2015/5; 65760937.604.01.01/68-506). The identity information of the students participating in the research has been anonymized and coded due to ethical concerns. 


\section{Findings}

In accordance with the research questions, a data-based framework driven by participant student discourses and a theory-based framework driven by the review of related literature, the results of the study are elaborated under two subheadings: (1) the reasons for studying architecture, (2) the contribution of architectural education to the development of professional skills. It is observed that the participants' views focused on the teaching approaches and the roles of instructors that are effective in architectural education, as well as the reasons for studying architecture and the basic knowledge and skills acquired during the architectural education. This framework has been effective in determining and categorizing the themes. The patterns grounded in the analysis of student responses regarding the first subheading are thematised according to the similarities of students' conceptions and educational experiences as follows: the creative dimension, the unity of thinking and doing, the social and family influence that inform the architecture students's choice(s) of profession. The second subheading addresses the two themes as design skills and practical-technical skills. Each of these themes will be examined in detail by discussing their relationships with the relevant literature.

\section{Reasons for Studying Architecture}

In the findings regarding the reasons for the participant students to study architecture, it was revealed that the three major issues were based on the creative dimension, the unity of thinking and doing and the influence of social and family environments.

\section{The Creative Dimension}

The findings under this theme mainly depend on the views that identify architecture with design, consider the design dimension of architecture as a field of freedom and point out that this freedom of design derives from the notion of creativity.

Architecture and the act of design are often seen as interrelated phenomena. In this study, the participant architecture students' statements indicated the sense that architecture is identified with the activity of design. The participants noted their understanding of the profession as combining the activities of design and creation and that the architect-as-designer is largely free to "express" his or her creativity in a project. Therefore, the student wanting to study architecture imagines himself/herself in the future firstly as a creator or designer. Some of the participants' stated that they had selected architecture as a program of study because it is a professional field that would allow them to express themselves creatively. This indicates that the architectural profession is seen as a way of self-expression for individuals (Gutman in Cuff \& Wriedt, 2010; Fisher 2006). The acts of designing, creating or producing are prioritized while choosing the profession that will occupy an important place in the rest of their lives. The following excerpts are examples of this perception:

"I have wanted to deal with art and design ever since I was a child. I want to express myself through channels other than writing. I want to do [create] whatever comes to my mind; I want to express myself in a different way, not through writing. I want to have something tangible in my hands. That's why I chose architecture." (Undergraduate, 2SEL, second-year) 
“... I am very liberal, for example, it had to be a profession in which I could feel free. I mean, it's a profession where I can do whatever I want, so I always searched for this." (Undergraduate, 2BAD, second-year)

The research participants reiterate that the preference for architecture as a field to study at the undergraduate level reflects two key factors: the personal interests of the individual himself/herself and the appeal of producing something tangible as a result of professional practice (i.e. a finished designed object), echoing an intersection of "artistic" and "realistic" interests of individuals that affect their vocational preferences as discussed by Holland (1959; 1997). The design dimension of architecture is seen as an area where the students can express themselves freely. This unfolds an example of career choice-making that is more congruent with personal interests and orientations of individuals as underlined in selfconcordance theory (Sheldon et al., 2019).

Comparing it with other professions, 4BAT notes the selection of architecture on the grounds it is an emancipatory and creative field: "I prefer to study architecture because it is more attractive than other professions; it is not a standardized field; we can shape something, and feel free while designing." When the design act is connected to individual creativity, it is attractive to students as an area that allows for the development of new and unique products that go beyond standard examples. This exemplifies how an individual associates an "interest" or "enjoyment" with a profession due to intrinsic motivation (Jung \& McCormick, 2011).

\section{The Unity of Thinking and Doing}

The thinking-doing unity dimension of architecture is another reason shaping participants' preferences to study architecture. This unity dwells on the co-existence of "artistic expression" and "human functions" in architectural design process (Lewis, 2013, p. 13). 3FAR relates this with the salience of the intersection of the act of design with art, which is seen as the focal point of the architectural profession: “... I considered being a sculptor or painter, but then I chose architecture. I feel lucky because I think it is a mixture of all of these elements [in the architecture field]." The participants of the study emphasize the potential of architecture to solve problems related to human life through design. For example, 2GÜLŞ argues that by practicing the profession of architecture, she can find solutions to the problems of the built environment in order to enhance people's living conditions. This view supports the emphasis given to the problem-solving part of the design as well as the creativity dimension. Thus, the "investigate" interest enmeshes with "social" interest as a motivation for the choice(s) of profession (Holland, 1959; 1997).

As some participants (3JiY and 4SAF) repeat at length, choosing architecture as a program of study is appealing because it allows-both through the period of education and later in professional practice-for the creation of tangible products that will stand as a public record of creative achievement. The value attributed to the profession of architecture becomes a showcase of the participants' belief in the importance of practicing as an architect and their aspiration to be recognized and respected by performing that practice (Jung and McCormick, 2011). This point is made directly in the words of 3iRE: "[It is about] producing something new, having something tangible as a result of working and feeling thankful for creating it." In a similar vein, 2BET considers architecture as "a great way to leave a mark" in the professional and/or social environment. This underscores the idea of intellectual satisfaction as a reason for 
studying architecture: students see transforming an abstract design idea into a design product (i.e. an architectural project) as a highly stimulating intellectual process.

According to the majority of the participants, architectural education differs from other education programs in terms of the theoretical learning process, the application-based production process, and the development of a product through the intersection of theoretical knowledge and imagination. Addressing whether architecture is a field of art, some participant students focus on the more prosaic aspects (i.e., the impact of architecture on the process of shaping the built environment). Along with the individual satisfaction that comes with creative design, architecture is preferred as a profession due to its potential to serve society through the creation of products that will contribute to the improvement of people's quality of life. In other words, more "intrinsic" orientations toward designing intersect with "extrinsic" professional and social goals of architecture under the effect of an "identified motivation" (Sheldon et al., 2019). According to participant 2BET, architecture combines individual reward through creative expression and the public good through contributing to the organization of the built environment.

\section{Social and Family Influence}

The potential of architecture to serve society fosters widespread perception of the professional social status of the architect. That the profession is seen as "prestigious" by most of the participants is a learned idea, developed over time through the influence of social factors-namely, the perceptions of family members or a pertinent role model in the students' social circle. The role models that students see in their environments affect their opinions, as noted by 2BAD: "The social relationships of architects, their perspective on the environment and their libertarian characteristics encouraged me to choose to study architecture." Being an architect is seen as offering the benefit of individual recognition and social status. This salience of social perception and status is apparent in the words of 3OZA:

"The first reason [for choosing architecture] is that I think its [the profession's] social status is very high; the second reason is the possibility of becoming widely known for a great project. Therefore, I chose it [architecture] because I think it is a promising profession." (Undergraduate, 3OZA, third-year)

The involvement of students' families in the field of architectural profession are among the most common factors for their choice(s) of profession. This is mostly observed in the families employed in the construction sector. Student 4 IŞI mentions that it is expected from them to participate indirectly into the family business by choosing architecture considered as a more prestigious profession than being employed in the construction field: "I tend to choose civil engineering until the last moment, but my father affected me by revealing the negative sides of the construction site. Therefore, I decided to study architecture." The case for 3FAR was just the opposite, whose parents discouraged him/her not to choose architecture with reference to their negative experiences related to the field: "My father did not encourage me to join the construction sector since he was working in the field, and he knew how hard it could be." In the study, the family has emerged as an "extrinsic" variable that affects the preferences of the participants to study architecture (Jung \& McCormick, 2011).

The results indicate that students choose to study architecture both to satisfy individual professional aspirations and due to personal characteristics. Considering the personal 
interests and abilities of the students as well as the potential of architectural design as a communication tool, the visual language and representational potential of the field influence students' profession preferences. Students tend to choose the profession that intersects both with environmental factors and their characteristics. 2BET mentions: "When I noticed this in profession choice-making process, I said yes; I think architecture is a great way for me to express myself and to add something new to the society." Many of the participant students self-report the interest in a profession they can enjoy, express themselves in, and that aligns with their skills and competencies. Underlining her interest in drawing since her childhood, 2GÜLŞ mentions: "Later on, I researched how I could continue this interest in my professional life and thought that architecture would be suitable for me." Therefore, the results show that an individual may be interested in more than one area or a profession may cover more than one area of interest according to the preferences of the individuals.

\section{The Contributions of Architectural Education to the Development of Professional Skills}

In the findings regarding the participants' responses about the contributions of architectural education to the development of professional skills, it was discovered that the two major issues were highlited as, (1) design skills and (2) practical-technical skills.

\section{Design Skills}

This part of the study evaluates the skills acquired by students after they start their architectural education. The findings reveal that before taking up a study program in architecture, students consider the practice of architecture and design as equivalent acts. This understanding seems to be continuing in the process of undergraduate architectural education. The participants state that the ability to "do" design is one of the basic skills acquired through architectural education. While comparing the knowledge and skills acquired in architectural design with the knowledge and skills content in other fields during their education, students conclude that they acquire most competence in design skills. The results of this study support the arguments that architectural education, and especially the design studio pedagogy, engenders the impression that the architect is primarily a designer skilled in the creative aspects of design (Nicol \& Pilling, 2005; Thompson, 2019).

"I think that the school mostly helps us cultivate design skills. After all, we do complex projects every semester. And that's why I also consider myself more competent in the field of architectural design compared to other areas." (Undergraduate, $4 B U R B D$, fourthyear)

The competence in design supported by undergraduate architectural education, mostly expressed by fourth-year undergraduate students, is also underlined by the newly graduated students. For example, MESEV mentions: ".. If our design skills were really lacking and we had not really done research, if we had not developed a design vision, it would have been a huge deficiency for us."

Architectural education encourages the student to manage the design process itself. That is, students of architecture are expected not only to "produce a final output," but also to master the skills of design and of executing the process of producing that output. The 
participant 4BAT points to the development of systematic thinking and discipline that comes through acquiring design skills. The field of architecture -which the participants associated with the notion of design before formal education began- starts to be defined as a practice involving diverse notions as the education process proceeds. This shows the variability of opinions about the profession before and after studying it formally. Students learn to seek alternative solutions to given design problems and they experience "learning by doing" during their architectural studies, which, they note, is a considerable difference from their high school education experience. While confronting a design problem, students develop skills in redefining the problem itself and searching for alternative solutions.

"Design is something free, but it needs to be disciplined. We know the processes of design and how to make stepwise improvements in it. We learned how to improve the discipline while learning design at university. Our education left us free in our thinking and the design process but also taught us how to organize it [the profession] as well." (Undergraduate, 4BAT, fourth-year)

The design act that shapes both architectural education and professional practise needs to be expressed through a language that is specific to architecture. The transformation of the design object in mind into both 2D drawings and 3D models is necessary to share the design thinking with other people and to ensure architectural communication. Students who attend architectural education directly from high school gain competence in various communication and representation techniques that allow them to transfer the architectural forms they develop conceptually into 2D and 3D media. As one participant (2SEL) states, although architectural education supports the cultivation of design skills, developing 3D thinking skills is a challenge. Unlike the common ability to draw, this skill cultivates the ability to think in 3D through the learning of architectural communication techniques. The results showed that studying architecture in the Bachelor of Architecture program has supported the "self-efficacy" beliefs of the students in design. As they developed design skills and improved their competencies in designing, their self-efficacy for the subject of architecture has increased (Patrick et al., 2011).

\section{Practical-Technical Skills}

Architecture is a field of profession and discipline with a focus on design, whereas the act of design is based on the synthesis of creativity, functionality, technical, aesthetic and social elements in architecture. Such conception of design is at the center of architectural education. Therefore, through the architectural education process, design skills should not be considered in isolation from practical and technical skills. However, the acquisition and the development of design skills are foregrounded in most schools of architecture, where the emphasis given to aesthetic concerns generally dominates the emphasis given to technical/practical/legal concerns in the design process (Gutman in Cuff \& Wriedt, 2010). The study findings reveal a general assumption that practical and technical skills continue to be learned in the field of professional practice. According to participant 4CAN, design and expression skills should be developed at the practical level as a part of the architectural education process. Participant $2 \mathrm{MEH}$ points out that once completing their studies, graduates who step onto the field of professional practice (i.e., a construction site or architecture firm) often feel not competent in, and insufficiently prepared for, professional practice. Architectural education is often criticized for not providing students with adequate practical experience. Participant students state that 
they have difficulties in transferring the theoretical dimensions emphasized during undergraduate education to the practical field.

"I think we are very good at designing and drawing, but we have problems in practice. Actually, I am interested in practice, but when I went to a construction site, I realized that I was not ready or prepared." (Undergraduate, 4CAN, fourth-year)

"I feel qualified as far as the design lessons are concerned, but I do not feel that qualified in the material and technical courses. I am very ambitious to learn things in these fieldsI do a lot of research. My imagination has no limits, so I want my design to be able to fit with technical requirements as well. I want to choose materials correctly [that are fit for purpose]." (Undergraduate, 2MEH, second-year)

While criticizing the deficiencies of architectural education in developing practical and technical skills, the participants seem aware of their responsibilities as well. They emphasize that research and other self-instruction skills should be included in undergraduate architectural education in addition to design skills (developing a project) and technical (application) skills. The fact that design is a practice-oriented activity should not be overlooked. As participant 3SU notes, students should broaden and improve the knowledge basis acquired in undergraduate architectural education through personal research effort. Unlike high school education-where knowledge is transferred from teacher to students, and the latter takes a passive role in the learning process - the findings here reflect the salience of the student-centered active learning approach that is effective in architectural education.

The results revealed that contrary to their design skills, architectural education delivered in the Bachelor of Architecture program did not support the "self-efficacy" beliefs of the students when it comes to the 'thinking-doing unity' in architecture. It was observed that before the participants started studying architecture, their awareness about the problem-solving potential and doing/producing dimensions of architecture was very high; however, the participants met on the common ground of the idea that the education they received provided them with limited technical knowledge and skills and not enough experience in the practice of architecture. Thus, it can be concluded that one of the factors that influence the participants' choice(s) of profession could not find enough response in their professional education.

\section{Conclusion, Discussion and Implications}

This study analyzed the main factors and interests that affect the undergraduate architecture students' choice(s) of profession before entering the school of architecture and revealed how their perceptions of their "self-concordance" and "self-efficacy" about becoming an architect have changed due to their professional education experiences. It is based on the personal experiences and perceptions conveyed by undergraduate architecture students in indepth interviews. The results of the study are categorized according to the reasons that participant students gave for studying architecture and the contribution of the Bachelor of Architecture program they entered to the cultivation of varied professional skills.

The results regarding the reasons for studying architecture has revealed that the participants are influenced by (1) their self-perceptions, which overlap with the professionrelated qualities and (2) the qualities in regard to social and family influence. The participants' self-perceptions that they harmonized with professional qualifications are mainly addressed as the central role of the design act and the unity of thinking and doing in architecture. It has been 
observed that the participants' beliefs and recognitions regarding architecture as a profession and a discipline are effective in their preferences of studying in the architecture department at the university. Their conception of design as the core activity of architecture designated to a job related-quality; while design is mostly declared as a notion congruent with their personal interests. Thus, the participants' perceptions of design and creativity are revealed to be congruent with their self-concordance and self-efficacy beliefs.

It is revealed in the study that the participant undergraduate architecture students' choice(s) of profession were also influenced by their belief in the unity of thinking and doing in architecture. The participants agreed that the intellectual process of design would conclude with a concrete product (project) with the aim of solving problems in order to increase the quality of human life. The study revealed that the participants consider the thinking-doing unity in architecture in accordance with their personal interests and orientations; furthermore, within a broader framework, its social impact and contribution to the visibility of the architect are emphasized. This job-related quality is seen congruent with the combination of "investigative" and "social interest", as well as "identified motivation" that is associated with a desire to acquire recognition from others (Sheldon et al., 2019).

It is also revealed in the study that the social and family influence are among the factors that affected the participants' choice(s) of profession before starting to study architecture at the university. For some participants, the belief in how the architect is perceived as a subject and professional practitioner in the society has been effective; some others underlined how family members currently working in the construction sector associated with architecture affected their choice(s) of profession, positively or negatively. It turns out that some of the participants who are exposed to social and family influence can remain indecisive, and in such a case, their personal interests and preferences inform their choice(s) of profession. Accordingly, apart from the social and family influence factor, the "deeper or more implicit personality preferences and potentials" of the students of architecture (Sheldon et al., 2019, p, 31 ), as well as the development of their self-accordance and self-efficacy are observed to shape their choice-making of a profession.

Looking at the reasons for the previous occupational preferences of the participants before they started studying architecture, it can be said that these preferences appeared as "self-stated goals" and that the "explicit conscious beliefs and processes" were effective in this process (Emmons, 1989, cited in Sheldon et al., 2019, Holliday, pp. 29-30). Particularly, the beliefs about the design-focus and the thinking-doing unity in architecture have influenced the participants' choice(s) of profession more consciously. However, the results of the study also revelaed that when the beliefs in social recognition and the family influence are at work, the participants' choice(s) of profession may result not from the "explicit conscious beliefs and processes" as intrinsic variables, but rather from "extrinsic variables." The choice(s) of profession regarding the emphasis they put on design and thinking-doing unity in architecture designates to an "intrinsically motivated behavior" (Deci \& Ryan, 1985; Ryan \& Deci, 2017; cited in Fouad et al., 2015, p.199). The influence of societal and family perceptions, on the other hand, designates to "extrinsic goals" such as "appearance, or status" (Sheldon et al., 2019 , p. 30). Thus, the effect of "identified motivation"' which means doing something because of the reason that it is important (Sheldon et al., 2019, p. 31) becomes obvious in the responses the participant architecture students gave regarding the reasons they preferred to study architecture. 
The choice(s) of profession of the indecisive students have revealed to be shaped with the increasing awareness about what they are interested in or which skills they have. For example, a student who likes to draw, see and observe different places, has been able to develop a belief that the profession of architecture is appropriate for her as her knowledge on this subject increases. Therefore, it is revealed that the participants' "self-accordance" increased as their awareness of "deeper or more implicit personality preferences and potentials" as well as their compatibility with architecture increased (Sheldon et al., 2019, p. 31).

The results of the study in regard to the contributions of architectural education to the development of professional skills revealed which skills were acquired and to what extent those skills supported the self-efficacy development of undergraduate architecture students. It is revealed that the way students considered the profession of architecture, as equivalent to the act of design was persistent before and after professional education of architecture. In other words, they perceived the architect primarily as a designer before they entered the school of architecture and this belief was supported through the acquisition and development of design skills. What is more, the education they were delivered at the Bachelor of Architecture program helped them discover the more complex nature of the design act as a process. As they developed the skills of systematic thinking and discipline, and as they cultivated a designspecific language of communication and representation, it is revealed that their beliefs in "selfefficacy" also increased. The belief of architecture students that they are prone to the profession increased as they gained experience in discipline-specific fields such as drawing, designing, field observations, etc. Thus, their "self-efficacy" also increased (Patrick et al., 2011). When the self-efficacy of a person increases in certain areas, his/her interest and success in that area also increases (Betz \& Borgen, 2000). According to the self-efficacy theory of Bandura (1986), "a person's beliefs about his or her ability to successfully perform a task play a major role in how well the individual performs any given task" (Wang et al., 2006, p. 315). The beliefs of the undergraduate architecture students that they have made a preference compatible with their personality increased as their design skills develop during professional education. Consequently, the participants are revealed to have developed a "firm attachment to a specific set of career goals" (Blustein et al., 1989, cited in Wang et al., 2006, pp. 312-313), after they started studying architecture in the Bachelor of Architecture program.

However, when the issue of thinking-doing unity is concerned the results are different. Although the participants' perceptions regarding the importance given to the thinking-doing unity in architecture persisted during their professional education, it appears that the experience related to the application is insufficient. The skills acquired from technical and vocational courses are seen as weaker compared to the cultivation of design skills. It can be concluded that the Bachelor of Architecture program did not support the development of students' perceptions of their self-efficacy in regard to practical-technical skills as much as they see themselves competent in designing. Nevertheless, the participants stated their belief that the development of practical-technical skills will not be limited to the scheduled professional education program but will develop as they gain experience in the field of professional practice. What is more, they demonstrated a self-awareness that they need to do more research to develop the practical-technical skills related to architecture during their professional education. Thus, the study revealed the participants' "identified motivation" in this regard (Sheldon et al., 2019, p. 31): we have to develop ourselves in practical-technical skills related to architecture, because a good architect must be skilled in these areas as much as having competency in design. 
The research findings have implications for (1) the students who think to study architecture as a professional program at the university, (2) the secondary education teachers, and (3) the administrators and instructors of schools of architecture. The research findings may contribute to increasing the awareness of the architectural profession in secondary education in two ways. Firstly, in addition to the social clichés about the architectural profession, the prospective students can be encouraged to understand the interrelated dynamics and requirements of the profession and the education of architecture. Secondly, for the secondary education teachers, the research findings can help guide the prospective students in their choice of profession in accordance not with social clichés, but with the realities of the profession of architecture and the architectural education and with the students' individual potentials/orientations. Thirdly, the research findings can contribute to any attempts by the administrators and instructors of schools of architecture to structure and implement a balanced architectural curriculum supporting both creativity and functionality, thinking and doing, design and implementation.

It is suggested that the findings of the study offer a framework inquiring, understanding and discussing the essential factors that influence students' perceptions and understandings of architecture both as a profession and a field of professional education. This study lays the groundwork for future research that would help students to choose a profession in accordance with their capabilities and orientations.

\section{Contribution Rate of the Researchers}

Author 1: Conceptualization, Methodology, Investigation, Writing-Original Draft, Project Administration, Funding Acquisition. Author 2: Methodology, Investigation, Writing-Review \& Editing. Author 3: Investigation, Writing- Reviewing and Editing.

\section{Support and Acknowledgment}

This work was supported by the Scientific and Technological Research Council of Turkey (TÜBITAK) under Grant 215K234. Special thanks to the students in the Department of Architecture at Altınbaş University, for their participation in the research.

\section{Conflict of Interest}

The authors declare that they have no conflict of interest. 


\section{Appendix A}

\section{Table 1}

The Student Participants of the Study

\begin{tabular}{|c|c|c|}
\hline $\begin{array}{l}\text { Participant } \\
\text { Code }\end{array}$ & Gender & Class Level \\
\hline 1ŞEV & Female & $1^{\text {st }}$ Year \\
\hline 1BiR & Male & $1^{\text {st }}$ Year \\
\hline 1RUM & Female & $1^{\text {st }}$ Year \\
\hline 1MER & Female & $1^{\text {st }}$ Year \\
\hline 1NES & Female & $1^{\text {st }}$ Year \\
\hline 1ELİ & Female & $1^{\text {st }}$ Year \\
\hline 1BER & Male & $1^{\text {st }}$ Year \\
\hline 2MUR & Male & $2^{\text {nd }}$ Year \\
\hline 2BAD & Female & $2^{\text {nd }}$ Year \\
\hline 2HİL & Female & $2^{\text {nd }}$ Year \\
\hline $2 \mathrm{MEH}$ & Male & $2^{\text {nd }}$ Year \\
\hline 2SEL & Female & $2^{\text {nd }}$ Year \\
\hline 2EFE & Male & $2^{\text {nd }}$ Year \\
\hline 2BET & Female & $2^{\text {nd }}$ Year \\
\hline 2SED & Female & $2^{\text {nd }}$ Year \\
\hline 2BİL & Female & $2^{\text {nd }}$ Year \\
\hline 2AŞK & Female & $2^{\text {nd }}$ Year \\
\hline 2GÜL & Female & $2^{\text {nd }}$ Year \\
\hline 2GÜLŞ & Female & $2^{\text {nd }}$ Year \\
\hline 2DEN & Female & $2^{\text {nd }}$ Year \\
\hline 3ERK & Male & $3^{\text {rd }}$ Year \\
\hline 3RAN & Female & $3^{\text {rd }}$ Year \\
\hline $3 S U$ & Female & $3^{\text {rd }}$ Year \\
\hline 3FAR & Female & $3^{\text {rd }}$ Year \\
\hline 3GÜR & Male & $3^{\text {rd }}$ Year \\
\hline 3İRE & Female & $3^{\text {rd }}$ Year \\
\hline $30 Z A$ & Male & $3^{\text {rd }}$ Year \\
\hline 3JiY & Female & $3^{\text {rd }}$ Year \\
\hline 3 sim & Female & $3^{\text {rd }}$ Year \\
\hline 3GÜL & Female & $3^{\text {rd }}$ Year \\
\hline 4ATA & Male & $4^{\text {th }}$ Year \\
\hline 4MER & Female & $4^{\text {th }}$ Year \\
\hline 4BAT & Male & $4^{\text {th }}$ Year \\
\hline 4BUS & Female & $4^{\text {th }}$ Year \\
\hline 4Hİ & Female & $4^{\text {th }}$ Year \\
\hline 4CAN & Male & $4^{\text {th }}$ Year \\
\hline 4SAF & Female & $4^{\text {th }}$ Year \\
\hline 4IŞ| & Female & $4^{\text {th }}$ Year \\
\hline 4SEV & Female & $4^{\text {th }}$ Year \\
\hline 4BAT & Male & $4^{\text {th }}$ Year \\
\hline
\end{tabular}




\section{References}

Albion, M. J. (2000). Career decision-making difficulties of adolescent boys and girls. Australian Journal of Career Development, 9(2), 14-19.

Betz, N. E., \& Borgen, F. H. (2000). The future of career assessment: Integrating vocational interests with self-efficacy and personal styles. Journal of Career Assessment, 8(4), 329-338. Retrieved February 1, 2018, from https://doi.org/10.1177/106907270000800402

Bandura, A. (1986). Social foundations of thought and action. Prentice Hall.

Bratcher, W. E. (1982). The influence of the family on career selection: A family systems perspective. Personnel \& Guidance Journal, 61(2), 87-91. Retrieved February 1, 2018, from https://doi.org/10.1002/j.2164-4918.1982.tb00734.x

Brown, S. D., Lent, R. W., \& Gore, P. A. (2000). Self-rated ability and self-efficacy beliefs: Are they empirically distinct? Journal of Career Assessment, 8(3), 223-235. Retrieved February 1, 2018,from https://doi.org/10.1177/106907270000800302

Care, E. (1996). The structure of interests related to college course destinations. Journal of Career Assessment, 4(1), 78-90. Retrieved February 1, 2018 from https://doi.org/10.1177/106907279600400105

Creswell, J. W. (2015). Qualitative inquiry and research design: Choosing among five approaches.(3rd ed.). Sage Publication.

Cuff, D., \& Wriedt, J. (Eds). (2010). Architecture from the outside in: Selected essays by Robert Gutman. Princeton Architectural Press.

Dagenais, F. (1998). Super's work values inventory scales as intrinsic or extrinsic constructs. Psychological Reports, 83, 197-198.

Deci, E. L., \& Ryan, R. M. (1985). Intrinsic motivation and self-determination in human behavior. Plenum Press.

Elsworth, G. R., Harvey-Beavis, A., Ainley, J., \& Fabris, S. (1999). Generic interests and school subject choice. Educational Research and Evaluation, 5(3), 290-318. Retrieved February 1, 2018 from 10.1076/edre.5.3.290.3882

Fisher, T. (2006). In the scheme of things: Alternative thinking on the practice of architecture (2nd ed.). University of Minnesota Press.

Fouad, N. A., Kim, S., Ghosh, A., Chang, W., \& Figueiredo, C. (2015). Family influence on career decision making: Validation in India and the United States. Journal of Career Assessment, 24(1), 197-212. Retrieved February 1, 2018, from https://doi.org/10.1177/1069072714565782

Gati, I., Krausz, M., \& Osipow, S.H. (1996). A taxonomy of difficulties in career decision making. Journal of Counseling Psychology, 43, 510-526. Retrieved May 8, 2021, from https://doi.org/10.1037/0022-0167.43.4.510

Groat, L., \& Wang, D. (2013). Architectural research methods. (2nd ed.). John Wiley \& Sons.Holland, J. L. (1959). A theory of vocational choice. Journal of Counseling Psychology, 6(1), 35-45. Retrieved February 1, 2018, from https://doi.org/10.1037/h0040767

Holland, J. L. (1997). Making vocational choices: A theory of vocational personalities and work environments. Psychological Assessment Resources.

İlerisoy, Z. Y., \& Aycı, H. (2019). Mimarlık son sınıf öğrencilerinin alan seçimlerine yönelik bir değerlendirme. JRES, 6(2), 192-214. Retrieved May 8, 2021, from https://dergipark.org.tr/tr/pub/etad/issue/51092/535161

Jung, J. Y., \& McCormick, J. (2011). The occupational decision: A cultural and motivational perspective. Journal of Career Assessment, 19(1), 75-91. Retrieved February 15, 2018, from https://doi.org/10.1177/1069072710382616

Lent, R. W., Brown, S. D., \& Larkin, K. C. (1986). Self-efficacy in the prediction of academic performance and perceived career options. Journal of Counseling Psychology, 33(3), 265-269. Retrieved February 15, 2018, from https://doi.org/10.1037/0022-0167.33.3.265

Lewis, R. K. (2013). Architect? A candid guide to the profession. (3rd ed.). MIT Press.

Marshall, C., \& Rossman, G. B. (2011). Designing qualitative research. (5th ed.). Sage Publications. 
Martincin, K., \& Stead, G. B. (2015). Five-factor model and difficulties in career decision making: A meta-analysis. Journal of Career Assessment, 23(1), 3-19. Retrieved February 15, 2018, from https://doi.org/10.1177/1069072714523081

Nauta, M. M. (2010). The development, evolution, and status of Holland's theory of vocational personalities: Reflections and future directions for counseling psychology. Journal of Counseling Psychology, 57(1), 11-22. Retrieved February 27, 2018, from 10.1037/a0018213

Neuandorf, K. A. (2017). The content analysis guide book. (2nd ed.). Sage.

Nicol, D., \& Pilling, S. (2005). Architectural education and the profession preparing for the future. In D. Nicol \& S. Pilling (Eds.), Changing architectural education: Towards a new professionalism (2nd ed., pp. 1-21). Taylor \& Francis Group.

Oakland, T., Stafford, M. E., Horton, C. B., \& Glutting, J. J. (Summer 2001). Temperament and vocational preferences: Age, gender, and racial-ethnic comparisons using the student styles questionnaire. Journal of Career Assessment, 9(3), 297-314. Retrieved February 27, 2018, from $10.1177 / 106907270100900306$

Patrick, L., Care, E., \& Ainley, M. (2011). The relationship between vocational interests, self-efficacy, and achievement in the prediction of educational pathways. Journal of Career Assessment, 19(1), 61-74. Retrieved February 27, 2018, from https://doi.org/10.1177/1069072710382615

Ryan, R. M., \& Deci, E. L. (2017). Self-determination theory: Basic psychological needs in motivation, development, and wellness. Guilford Press.

Schreier, M. (2012). Qualitative content analysis in practice. London: Sage Publications.

Schulenberg, J. E., Vondracek, F. W., \& Crouter, A. C. (1984). The influence of the family on vocational development. Journal of Marriage \& Family, 46(1), 129-143. Retrieved February 27, 2018, from https://doi.org/10.2307/351871

Sheldon, K. M., Holliday, G., Titova, L., \& Benson, C. (January 2019). Comparing Holland and selfdetermination theory measures of career preference as predictors of career choice. Journal of Career Assessment, 28(1), 1-15. Retrieved March 01, 2020, from 10.1177/1069072718823003

Super, D. E. (1970). Manual: The work values inventory. Riverside.

Super, D. E. (1973). The work values inventory. In D. Zytowski (Ed.), Contemporary approaches to interest measurement (pp. 189-205). University of Minnesota Press.

Stufflebeam, D. L. (2003). The CIPP model for evaluation. Portland, Oregon: Annual Conference on the Oregon Program Evaluators Network (OPEN).

Tang, M. (February 2009). Examining the application of Holland's theory to vocational interests and choices of Chinese college students. Journal of Career Assessment, 17(1), 86-98. Retrieved March 01, 2020, from 10.1177/1069072708325743

Thompson, J. (2019). Narratives of architectural education: From student to architect. Routledge.

$\mathrm{Xu}, \mathrm{H}$. (June 2019). Development and initial validation of the constructivist beliefs in the career decision-making scale. Journal of Career Assessment, 28(2),1-17. Retrieved March 01, 2020, from $10.1177 / 1069072719845668$

Ulrich, D. N., \& Dunne, H. P. (1986). To love and to work: A systematic interlocking of family, workplace, and career. Brunner Mazel.

Wang, N., Jome, L. M., Haase, R. F., \& Bruch, M. A. (2006). The role of personality and career decision-making: Self-efficacy in the career choice commitment of college students. Journal of Career Assessment, 14(3), 312-332. Retrieved March 01, 2020, from $10.1177 / 1069072706286474$

Weber, R. P. (1990). Basic content analysis. (2nd ed.). Sage Publications.

Whiston, S. C., \& Keller, B. K. (2004). The influences of the family of origin on career development: A review and analysis. Counseling Psychologist, 32(4), 493-568. Retrieved March 01, 2020, from https://doi.org/10.1177/0011000004265660 